\title{
Law Enforcement Activities of the Criminal Executive Special Forces Associated with the Use of Coercive Measures
}

\author{
Sergey Vladimirovich Ponikarov ${ }^{*}$, Vladimir Anatolievich Ponikarov², Tatyana Nikolaevna \\ Dazmarova $^{2}$, Andrey Vladimirovich Zverev ${ }^{2}$, and Vasily Nikolaevich Chorny ${ }^{3}$ \\ ${ }^{1}$ Academy of Law and Management of the Federal Penitentiary Service of Russia (Academy of the \\ Federal Penitentiary Service of Russia), Department of Management and Organization of the \\ Penitentiary System (UIS), Ryazan,Russia \\ ${ }^{2}$ Academy of Law and Management of the Federal Penitentiary Service of Russia (Academy of the \\ Federal Penitentiary Service of Russia), Department of Administrative and Financial Law, Ryazan, \\ Russia \\ ${ }^{3}$ Academy of Law and Management of the Federal Penitentiary Service of Russia (Academy of the \\ Federal Penitentiary Service of Russia), Department of Penal Law, Ryazan, Russia
}

\begin{abstract}
Research prerequisites: Insufficient scientific knowledge of this issue dictates the advisability of considering and studying this topic. For the first time, the article highlights the legal aspects associated with the use of methods of struggle, special means, and military weapons by employees of special-purpose units of the criminal-executive (penitentiary) system of Russia. The paper states that only for the commission of criminal offences, it is possible to use military weapons by special forces units of the Federal Penitentiary Service and special escorting divisions of the criminalexecutive system of the Russian Federation. Purpose of the research: to investigate the law enforcement activities of the penitentiary special forces associated with the use of coercive measures including for criminal offences. Methods: when considering the essence of coercive measures in the law enforcement activities of special-purpose units, the article used the dialectical method. To formulate the conditions for the correct (legal) use of weapons in law enforcement directly by employees of special-purpose units of the Russian penitentiary system, systematized methods were used. The empirical method was used when interviewing special forces officers in the investigated activities. Results and novelty: the scientific result of this article is the first formulated many components aimed at improving the measures of coercion. In particular, the grounds for the correct use of methods of struggle, special means, and military weapons are proposed. The article identifies situations (circumstances) associated with a real threat to the life and health of a special-purpose employee. The negative and positive aspects associated with the use of coercive measures are emphasized.
\end{abstract}

*Corresponding author: Minrs@yandex.ru 
Keywords:law enforcement, special equipment, military weapons, special forces officers of the criminal-executive system

\section{Introduction}

Some issues related to the use of coercive measures in the law enforcement activities of special forces officers were analysed in a specific scientific work [1]. General issues of state coercion are set out in the scientific work [2]. Other works concerned only the organisation of the activities of separate law enforcement agencies [3]. Still others concerned the personality of the offender against whom the investigated measures were applied [4, p. 268273].

It should be noted that at the end of December 2016, amendments were made to the legislative acts regulating the use of coercive measures (See Law of the Russian Federation dated July 21, 1993 No. 5473-1 On Institutions and Bodies Executing Criminal Sentences in the Form of Imprisonment). The article examines the measures of coercion used by the employees of the special-purpose units of the penitentiary system including for the commission of criminal offences.

In the presented work, many aspects aimed at improving the process of using combat methods of struggle and special equipment and military weapons are scientifically formulated. There are statistical studies recorded in the presented work. Thus, everything of the above determines the relevance of the topic of the scientific article.

\section{$2 \quad$ Methods}

The research was based on the general scientific dialectical method. For the development of coercive measures in law enforcement directly by employees of the special-purpose units of the penitentiary system, grouped methods were used. They made it possible to systematize the content of coercive measures. To consider the prospects for the development of coercive measures in the activities of prison special forces officers, applied methods of comprehension are applied. Within the framework of the article, about 200 employees of special forces were interviewed.

\section{Discussion}

An analysis of the current legislation allows saying that earlier special forces officers used measures in prison and the adjacent territory in which regime requirements were established, as well as in guarded facilities. At the moment, their law enforcement service is not limited only to the boundaries of the prison. They also perform the functions of escorting.

As a result, the legislator amended Article 28 of the law of the Russian Federation on Institutions and Bodies Executing Criminal Sentences in the Form of Imprisonment, according to which special forces officers have the right to use physical force, special equipment, and firearms in the following cases:

1) in the territories of institutions executing punishment;

2) in pre-trial detention centres and adjacent territories in which regime requirements are established;

3 ) at the guarded facilities of the criminal-executive system;

4) while performing escort duties. 
The legislator suggested the principle of territoriality. It is in these places that the special forces officers, as well as the operational units' staff, have the right to apply coercive measures (physical force, special equipment, and military weapons) [5, pp. 70-79].

It should be noted that in the foreign aspect, the powers of such special forces go beyond the territory of the prison (that is, foreign special forces officers can apply these measures outside the penitentiary, as this ensures the security of the object [6]. For example, French gendarmes have this right $[7$, p. $25 ; 8$, p. 56]. At the same time, the emphasis is placed on the observance of human rights, the legality of application [9], as well as self-control in the implementation of these measures [10]. One should note the fact that the foreign prison inspection (special forces) also has the right to use weapons outside the prison [11]. However, in foreign penitentiary institutions, they very strictly monitor that there would be no torture or other harsh, inhuman treatment [12].

In the further discussion, the question arises: "Can a prison special forces officer apply these measures (methods of struggle, special equipment, and military weapons) in other places?"

This question is answered by the provisions of Article 28 of the law of the Russian Federation On Institutions and Bodies Executing Criminal Sentences in the Form of Imprisonment. After the word escort, the legislator proposed the following: "and in other cases established by that law".

That is, Article 28 of the law of the Russian Federation On Institutions and Bodies Executing Criminal Sentences in the Form of Imprisonment refers to Article 31.2 (Use of Weapons) which, in turn, records cases related to the use of military weapons. There are also specific episodes related to the application of the measures under consideration.

Thus, special forces officers of the prison system have the right to use physical force, special equipment, and firearms in the cases intended by Articles 29, 30, and 31.2 of the law in question.

So, an employee of a special purpose unit when using special equipment or weapons in practice must remember three conditions:

1) the legal grounds of the application of these measures;

2) the proportionality of the application of these measures;

3 ) the threat to life and health must be real, but not considered (imaginary).

An employee of a special forces unit is obliged to review his own behaviour.

The analysed law does not allow hitting a person with a special rubber stick (PRS-73) on the head, neck, clavicles, abdomen, genitals, or in the area of the projection of the heart. However, it allows derogation from prohibitions and restrictions if special equipment is used on the grounds provided for by Article 31.2 of the law of the Russian Federation On Institutions and Bodies Executing Criminal Sentences in the Form of Imprisonment.

Once again, it should be emphasised that special forces officers must take into account that the threat of an attack from the convict must be real, that is, the employee must suffer (for example, receive a bodily injury, scratches on the body, blood and other injuries).

\section{$4 \quad$ Results}

Many foreign special forces units always adhere to three basic principles: never make concessions to terrorists; no negotiations with criminals; ensuring the unavoidability of punishment [13, pp. 15-17].

A survey of special forces employees of the penitentiary system showed that they mostly used combat methods of struggle, and only then special equipment. Weapons are rarely used by them, but many reported that they often used similar measures against violators. Special forces employees stated that for the correct and legal application of these measures, it is necessary: 
1) to teach each special forces officer to use a department-issued sidearm;

2) to achieve excellent shooting;

3) to practice conducting classes in extreme conditions;

4) to carry out more practical exercises at the shooting ground.

Table 1.A survey of practical special forces officers (200 people).

\begin{tabular}{|l|c|c|}
\hline Do you often use coercive measures in your law enforcement activities? \\
\hline Yes & 150 & $80 \%$ \\
\hline No & 20 & $8 \%$ \\
\hline Undecided & 30 & $12 \%$ \\
\hline
\end{tabular}

The authors' research has shown that not all employees of the penitentiary special forces consider their knowledge and skills sufficient to fulfil the assigned tasks in the field of law enforcement activities related to the use of coercive measures. The interviewed special forces soldiers assessed their level of training in the application of these measures as follows: physically prepared $-71.5 \%$; it is required to increase the level of physical fitness $-12.5 \%$; additional psychological preparation is required $-16 \%$.

When training the personnel of the special forces of penitentiary units in the use of methods of struggle, special equipment, and military weapons, according to the officers themselves, attention should be paid to: psychological training (10\%); physical fitness, and endurance (10.5\%); tactical techniques and methods of specific actions (11.5\%); all skills and abilities must be used in a complex, without giving preference to any direction (68\%).

It should be noted that not every person is capable of using deadly force. Therefore, psychological training is very important for a special forces soldier.

For the lawful application of coercive measures, the next element in the training system for a fighter of a special-purpose unit is physical training, including: possession of various kinds of wrestling techniques (sambo, judo); development of physical strength, agility, and endurance.

Physical training is closely related to combat training which occupies one of the leading places in the system of law enforcement activities of special forces.

A very important emphasis is placed on the fact that when applying coercive measures, an officer of the penitentiary special forces should act combat-wisely in difficult and nonstandard situations, make independent legal decisions, and perform assigned tasks. By the way, in many foreign countries (France, Spain, Portugal, Germany) when selecting candidates for service in special police units, priority is given to those who are able to think combat-wisely when using coercive measures. They mainly focus on the "effect of mental strength training" in police special forces [14].

It is also worth noting that during the period of their activity, the penitentiary special forces acquired the relevant experience associated with the use of coercive measures. It is also important to say that in the departmental press, public councils of former employees of special forces on measures of coercion, for example, the use of firearms, in particular, pistols began to appear. A detailed study of the proposed methods can very positively affect the practical application of the analysed measures, which has a positive effect on the operational environment in the correctional institution [15].

Most importantly, when using coercive measures (especially using weapons), it is necessary to collect evidence (photos, videos, testimonies of witnesses). The authors note that in foreign countries, all is not that right in the field of the subjects of evidence, where the main evidence is the report of the police officer who used the weapon [16, p. 100]. 


\section{Conclusion}

New legal aspects in the law of the Russian Federation On Institutions and Bodies Executing Criminal Punishments in the Form of Imprisonment contain both negative and positive aspects.

The first side includes the fact that the law does not actually specify particular protected objects. For example, it is not clear if educational and scientific institutions of the penal system are considered to be such objects? Or, for example, industrial facilities (sawmills) or hospitals (for convicts). The law does not say anything about this.

The second component must include the fact that special forces officers have the right to apply coercive measures in other cases established by the law of the Russian Federation On Institutions and Bodies Executing Criminal Punishments in the Form of Imprisonment. The provisions of the article can be used in the educational process, as well as in order to improve the qualifications of prison staff.

\section{References}

1. V.A. Ponikarov, I.N. Kalutskii, S.M. Smolev, S.V. Stroilov, Man: Crime and Punishment 25(3), 384-389 (2017)

2. N.V. Makareiko, Gosudarstvennoe prinuzhdeniyu v mekhanizme obespecheniya ekonomicheskoi bezopasnosti: teoretiko-prikladnye problemy [State coercion in the mechanism of ensuring economic security: theoretical and applied problems], Ph.D. Thesis (Nizhny Novgorod Academy of the Ministry of Internal Affairs of Russia, Nizhny Novgorod, 2016)

3. N.V. Babich, Pravovoe regulirovanie i organizatsiya deyatelnosti organov predvaritelno sledstviya v Rossiiskoi Federatsii [Legal regulation and organization of the activities of the bodies of preliminary investigation in the Russian Federation], Ph.D. Thesis Abstract (RUDN University, Moscow, 2019)

4. A.I. Dolgova, Lichnost organizovannogo prestupnika: kriminologicheskoe issledovanie: monografiya [The personality of the organized criminal: criminological research: monograph] (Norma: INFRA-M, Moscow, 2020)

5. V.A. Ponikarov, S.V. Ponikarov, K.A. Chistyakov, S.A. Yunusov. Administrativnopravovoi status sotrudnikov operativnykh podrazdelenii FSIN Rossii: uchebnoe posobie [Administrative and legal status of employees of operational units of the Federal Penitentiary Service of Russia: a tutorial] (Prospekt: Academy of the Federal Penitentiary Service of Russia, Moscow, 2019)

6. O. Lobel, Admin. Law Rev. 57(4), 1071-1151 (2015)

7. M. Prelo, Organisation de la peinejudiciaireen France (Paris, 2017). P. 25

8. N. Bordeaux, Direction d'Etat, autorités de police de la France (Marcel, 2019). P. 56.

9. L. Rhodes. Comp. Civiliz. Rev. 82(82), Art. 5 (2020)

10. M. Buchhandler-Raphael. Fordham Law Rev. 88(5), 1815 (2020)

11. M. Rogan. Eur. J. Crim. Policy Res. 45-48 (2019). https://doi.org/10.1007/s10610019-09420-8

12. M. Picchi, Crim. Law Forum 28(4), 749-776 (2017). https://doi.org/10.1007/s10609017-9306-y

13. N.Y. Hedmi, Features of Countering Crime in Israel (Tel Aviv, 2016) 
14. R. van der Meulen, M.W.G. Bosmans, K.M.E. Lens, E. Lahlah, P.G. van der Velden. J. Police Crim. Psychol. 33(4), 385-397 (2018). https://doi.org/10.1007/s11896-0179247-8

15. M.A.Kirillov, V.G. Gromov. Legal Science and Practice: Journal of Nizhny Novgorod Academy of the Ministry of Internal Affairs of Russia 2(30), 72-75 (2015)

16. V.A. Ponikarov, L.V.Pavlova, E.V. Senatova, Institut dokazyvaniya po delam ob administrativnykh pravonarusheniyakh $\mathrm{v}$ pravookhranitelnoi deyatelnosti ispravitelnykh uchrezhdeniii sledstvennykh izolyatorov FSIN Rossii: monografiya [Institute of evidence in cases of administrative offenses in law enforcement activities of correctional institutions and detention centres of the Federal Penitentiary Service of Russia: monograph] (Prospekt: Academy of the Federal Penitentiary Service of Russia, Moscow, 2017) 